\title{
The Political Market and Sustainability Policy
}

\author{
Richard C. Feiock ${ }^{1}$ and Soyoung Kim ${ }^{2, *}$ \\ 1 Local Governance Lab, Local Governance Research LLC, Tallahassee, FL 32303, USA; \\ rfeiock@fsu.edu or rfeiock@gmail.com \\ 2 School of Liberal Arts, Seoul National University of Science and Technology, Seoul 01811, Korea \\ * Correspondence: soyoung.kim@seoultech.ac.kr
}

check for updates

Citation: Feiock, R.C.; Kim, S. The Political Market and Sustainability Policy. Sustainability 2021, 13, 3344. https://doi.org/10.3390/su13063344

Academic Editor: Philipp Aerni

Received: 31 December 2020

Accepted: 16 March 2021

Published: 18 March 2021

Publisher's Note: MDPI stays neutral with regard to jurisdictional claims in published maps and institutional affiliations.

Copyright: (c) 2021 by the authors. Licensee MDPI, Basel, Switzerland. This article is an open access article distributed under the terms and conditions of the Creative Commons Attribution (CC BY) license (https:/ / creativecommons.org/licenses/by/ $4.0 /)$.

\begin{abstract}
This essay introduces the political market framework (PMF) and discusses its implications for understanding local sustainability policy. The PMF conceptualizes public policy related to sustainability as the product of exchange between governmental policy suppliers and voter and interest group policy demanders. After presenting a political market model, the role of political institutions is introduced. Institutions structure exchange relationships by determining transaction costs of searching for mutually beneficial agreements, bargaining over outcomes, and monitoring and enforcing decisions. The central implication for research is the need to account for the moderating role that political institutions play in sustainability policy decisions. A research agenda based on the PMF is advanced. The conclusion addresses the limitations of the framework as well as its implications for policy adoptions, program designs, and individual behavior.
\end{abstract}

Keywords: political market; institutions; local governance; political incentives

\section{Introduction}

The political market framework (PMF) describes exchanges between government officials responsible for sustainability policy and the groups that have a stake in those policies. This framing reflects the insight that policies enacted by governments are responsive to instrumental political resources received by public officials from the specific citizens, interests, and constituency groups that benefit from those policies [1,2]. Outcomes are shaped by the political resources and powers of policy demanders and the preferences of government policy suppliers under different institutional arrangements.

Political transactions are characterized by governmental officials' efforts to design programs that deliver benefits to the groups expressing policy demands [3,4]. Policy design decisions reflect government officials' time and the extent to which their personal/ideological preferences for particular policy outcomes are consistent with the demanders' preference [5-7].

The PMF has generated interest and applications in empirical studies across a diverse set of policy areas related to sustainability. Research has examined economic development, resource conservation, service delivery, transportation, land use, and energy [8-12]. Despite its empirical usefulness, a full exposition of the framework and its application to sustainability policy is conspicuously absent in the literature. This essay begins to fill this lacuna by describing the framework and its components and providing real-world examples of some of its more abstract concepts. It also more fully articulates its implications for sustainability policy adoptions, program designs, and individual behavior.

\section{The Political Market Approach}

The political market approach builds on political science research that extends transaction cost economic theories to policymaking $[5,13,14]$. Transaction costs are any costs incurred in making exchanges such as search, bargaining, decision-making, and enforcement costs [15-18]. Political transactions involve governmental official's efforts to deliver durable benefits to constituents for which they can claim credit. The PMF connects transaction costs faced by individuals and groups to the design of public policies. 
Dixit [5] argues that transaction costs are relevant to both institutional and policy choices. Institutional analysis is typically about the policy choices of executives, legislators, bureaucrats, and other relevant actors to address a collective problem. An often-neglected element of policy analysis is the real-world transaction costs that characterize political exchange. In the private sector Williamson demonstrates that transaction costs associated with limited information (bounded rationality), ex-post opportunism, and asset specificity can be reduced through specific types of contractual arrangements or governance structures [19-21]. Certain institutional arrangements reduce uncertainties by replacing high-power market incentives with lower power bureaucratic incentives that help secure the contract and reduce uncertainty $[20,22]$. A similar logic can be applied to examine local government institutions $[23,24]$. Institutional constraints create transaction costs since time and resources must be expended to overcome them $[15,16,25,26]$.

Sustainability policy can be viewed as the product of a dynamic contracting process between the suppliers and demanders of policy, leading to an alignment of governmental policy with constituent demands. In its simplest form, the political market focuses on the exchange between elected officials and constituent interest groups in which local government officials supply policies in exchange for political resources such as votes, campaign contributions, media exposure, etc. The negotiated policy designs reflect the relative political power of the various demanders, and the willingness of government authorities to supply policies favorable to these various interests. In order to provide context, Figure 1 depicts a simple political market for which the marginal cost to governmental officials of supplying the policy equals the marginal political benefit they receive. This simple model aggregates the policy demands of various interests into a single demand curve. It also aggregates motivations for the willingness of government officials to supply specific policies into a supply curve.

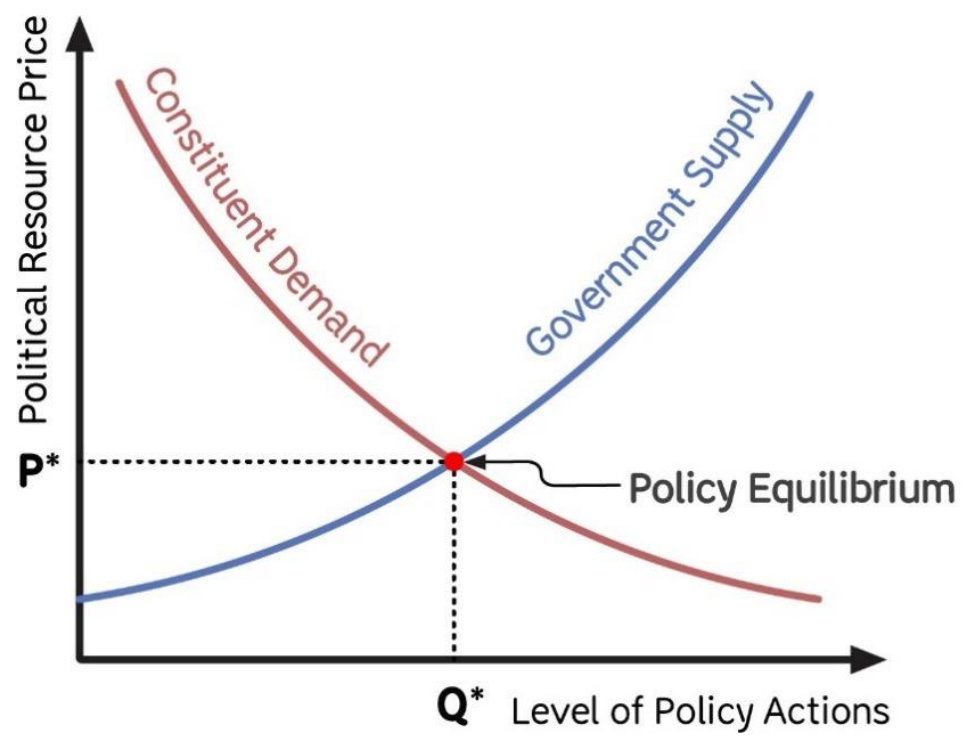

Figure 1. A simple political market.

Policy Demand. Demanders want public policies to be designed in a manner that will benefit them. Policy demanders can include the broader public as well as private interests seeking to secure favorable outcomes in the political arena. Demanders can express their support for officials through votes, contributions, or other instrumental political resources. Some interests are better at organizing for collective action than others, and therefore are better able to articulate their policy preferences and more effectively participate in political decision-making [27].

Policy Supply. Governmental officials seek to deliver durable benefits to specific constituencies through the policies they supply. Frant [22] argues that this type of exchange is characterized by high-power policy incentives - the public sector equivalent of high- 
power market transactions [20]. Policy support is exchanged for the private benefits that result from policy actions. In addition to electoral benefits or costs resulting from the alignment of policy with demanders' interests, governmental suppliers face transaction costs arising from the time and effort to reach an agreement on policy design and the costs of deviating their own preferred policy. In Figure 1, a competitive equilibrium is given by the intersection of the policy-support supply function and aggregated demands. Levels of support by individual government officials are thus equivalent to the amounts they are willing to provide at the competitive equilibrium "price", i.e., the point of intersection of their supply functions with the demand they face [24,28]. Thus, policy choice depends upon the relative degrees of support generated for various alternatives.

\section{Transaction Costs}

Since policy choices are framed as the product of strategic market calculations of the participants, this simple model offers a parsimonious depiction of a complex process. This is an oversimplified version of the political market since it does not include political institutions. Nevertheless, the approach does not impose restrictive assumptions such as perfect rationality or complete information. Instead, it only assumes intendedly rational goal-directed behavior on the part of the actors [8]. The interests of policymakers are linked to career advancement, but their interests can include program effectiveness, efficiency, equity, or other valued goals [29]. The complex goals, cognitive limitations, uncertainties, and information limitations are what give rise to the transaction cost central to the PMF [30].

Transaction costs are ubiquitous in political exchange [31]. In the PMF, the transaction costs can include political bargaining costs, commitment costs, agency costs, and information costs [3,32]. Even if a government official is able to deliver the desired program or policy, future political support from the benefiting groups is not guaranteed. This is because a beneficiary group may not be able to mobilize its members to support the official in the future. Demanders face uncertainties in political exchange as well because there is no guarantee that officials will keep their commitments and successfully follow-through in implementing the policies $[3,5]$. There is also the risk that the officials currently in place will not hold their position in the future, leading to policy change or reversal. This uncertainty is a commitment problem for the long-term benefit flows of policy decisions. Threats to the durability of policy benefits can result from the potential of future leaders to amend or repeal a policy [10]. In addition, administrators may not faithfully comply with the original intentions of the policymakers or the goals of the policy, in the implementation process.

\section{The Role of Institutions}

What distinguishes the political market framework advanced by Feiock and his associates, is its focus on political institutions $[8,9,11,24]$. The simple political market depicted in Figure 1 offers insights into the link between motivations and outcomes, but it ignores political institutions that determine how specific demands and supply motivations are aggregated and articulated. The simple model treats institutions as transparent to underlying economic or political forces driving policy actions. The key innovation of the PMF is to assign a central role to government institutions as the arena in which political contracting occurs $[8,9,24]$. Examples of relevant political institutions would include separation of executive, legislative and judicial powers, district vs. at-large representation, terms of legislators, the role of parties, and whether the implementation is the responsibility of bureaucratic managers or elected executives [33]. Institutions combine with the structure of interest organization to function as moderators of the political and socioeconomic forces motivating the actors [34,35]. Different political institutions will favor different types of interests, either enhancing or reducing their ability to influence policy. There are often multiple policy equilibria since each distributes the costs and benefits of policy change in a different way. The aggregation of diverse policy demands is further complicated by the possibilities of free-riding on the collective benefits of public goods. Political institutions shape these barriers to collective action and advantage groups with specific 
types of resources $[25,36,37]$. We argue that the structure of local political institutions will facilitate or impede the influence of specific demands and community interests on sustainability policy decisions. Political institutions affect the ability of interests to articulate their demands, and the willingness of elected officials and bureaucrats to supply the demanded policies. An example illustrates how the political process will change as a function of different institutional arrangements. A study of local governments in the US examined the influence of business vs. environmental interests on policy choice in cities where legislators were elected citywide (at-large) or elected from districts [9]. Because of the geographic basis of representation in municipalities with district elections, environmental and neighborhood interests were empowered, while the influence of development interests was diminished. Conversely, at-large elections forced local legislators to respond to a much broader set of political interests than are typically found in a single district, and thus favored well-organized, business interests with resources to provide instrumental political resources. The result is that the positive effect of environmental interests on conservation actions is increased in political systems with district elections, and the negative effect of development interests on conservation is increased under at-large electoral representation.

Political institutions are sometimes treated as causing policy. Instead, the PMF views the role of institutions as interactive, modifying variables that either facilitate or inhibit the translation of demands into policy outputs [38,39]. Many empirical studies treat institutions as directly influencing sustainability policy decisions, testing only for the additive effects, based upon a misunderstanding of the role of institutions as mechanisms to aggregate preferences $[40,41]$. PMF treats the institutions of government as mechanisms for mediating and moderating conflict and for aggregating and articulating individual and group preferences. For example, in forms of US local governments with an appointed city administrator, rather than an elected mayor as executive, government policy suppliers are more insulated from citizen pressures and popular demands. This leads them to favor economic over environmental interests since economic interests are better able to supply instrumental political resources. The diagram of the political market in Figure 2 highlights the moderating role of institutions in policy choices. PMF treats the institutions of government as mechanisms for moderating conflict and for aggregating and articulating individual and group preferences. (Frequently, moderation is discussed with mediation conceptually and empirically, however, the concept of moderator describes activities and effects differently from that of mediator [42]. The mediator is defined as the 3rd party between two others and the key role of mediator is a linkage or a channel between two parties [43-45]. However, the moderator is conceptually, statistically, and practically different from the mediator in that it is influencing the relationships between two parties in terms of strength, size, direction (positive or negative) of interventions and therefore, outcomes [43-45]).

In this framework, the institutional effect is activated between the demand-supply and policy choices as a moderator, which influences, changes, strengthens, or weakens relationships and interventions [45]. Moderation is the function affecting the existence of the effect, the strength of intervention, the size and direction (positive or negative) of the relationship [42,43]. When the institution moderates the effect of one party over another, it means the relationship depends on the institution and that relationship is contingent or conditional on the moderator [42]. 


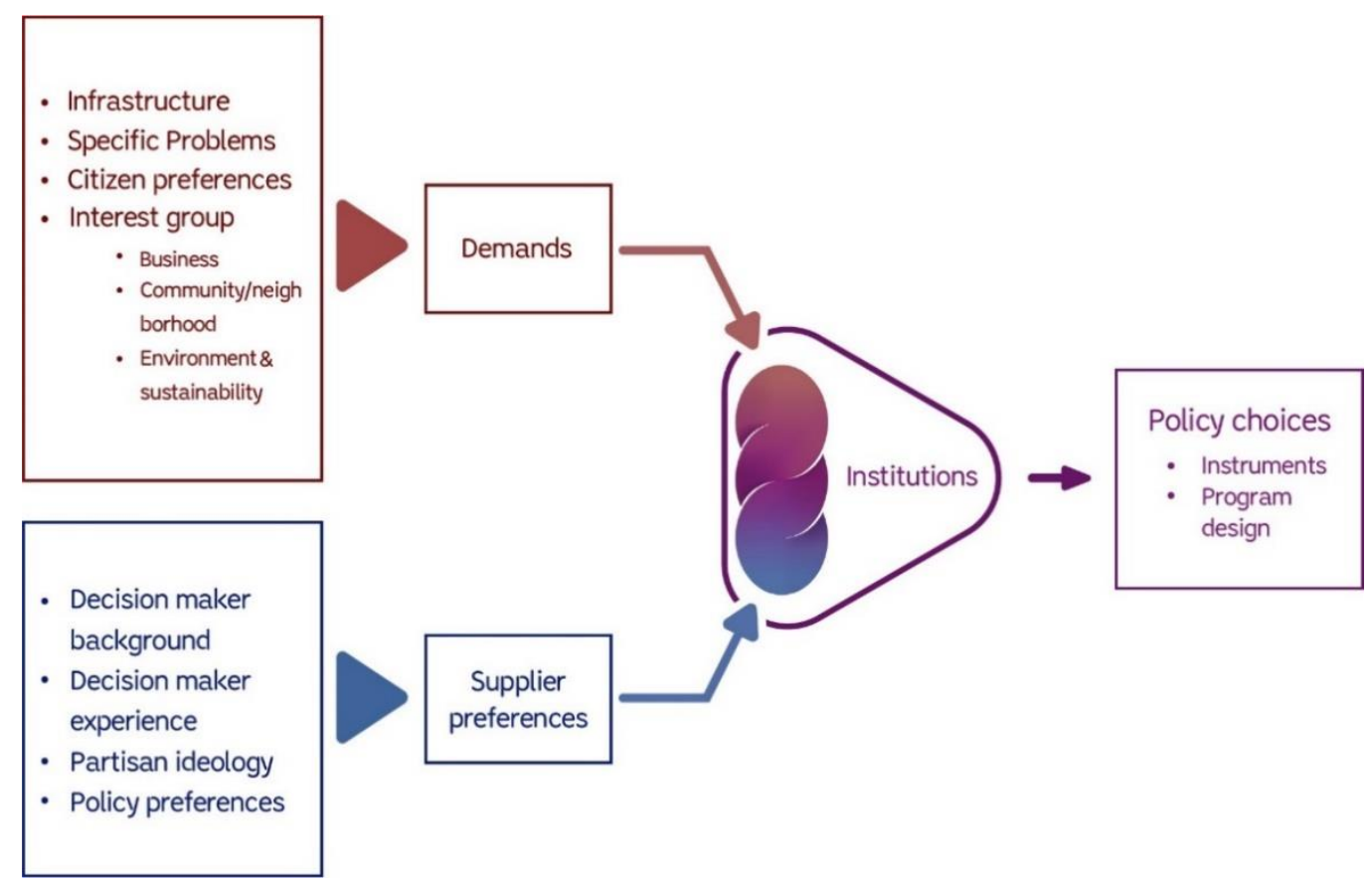

Figure 2. The political market framework.

\section{Policy Choice and Program Design}

PMF provides a framework that can inform understanding of the policy process at multiple levels including policy adoptions and program designs. While much of the existing literature has applied PMF to examine smart growth and sustainability policy adoption or policy change [46,47], at this level that the political market conceptualization is quite abstract. Nevertheless, applications of PMF to policy adoptions have produced new knowledge and identified previously unrecognized institutional effects [34]. For example, Lubell, Feiock, and Ramirez [8,9] identified systematic biases induced by local government institutions on adoptions of development and sustainability policy. They found that demands of developers' interests were amplified and that residential and environmental interests muted where cities had a council-manager form of government. Alternatively, where cities had strong popularly elected mayors, development demands were constrained, and environmental interests were empowered. Across multiple policy areas such as transportation, land use, sustainability, institutions such as city managers, district representation, and direct democracy have been found to shape the influence of specific demands on policy choices.

This body of work provides strong and consistent evidence that institutions shape the relative influence of supply and demand preferences on policy choices [48]. Intergovernmental institutions are also linked to the local policy since federal or state constraints structure and incentivize local actions [49]. State or national laws and institutions may increase or decrease the costs associated with pursuing particular policy goals. Thus, intergovernmental institutions can induce certain outcomes by determining what policies are in interests of local citizens and public officials. For example, decentralized systems with a greater number of access points provide more opportunities to block change, but they can also be more responsive to disadvantaged groups.

The design of policy instruments is often the product of bargaining and political conflict based on the consequences of program design decisions for the distribution of benefits and cost. The constituencies at the policy design stage are narrower and more specialized than those at the policy adoption since the process is more arcane and less visible [50]. Curley, $\mathrm{Xu}$, and Feiock [30] argue that instruments can be designed to reach different demographic constituencies, and thus, may lead policymakers to design policies 
to construct a constituency of policy beneficiaries to match their interests-thus linking policy design and constituent behaviors.

\section{Discussion}

The political market framework (PMF) conceptualizes policy as the product of exchange between government policy suppliers and interest group policy demanders. Political institutions structure this exchange relationship by determining the transaction costs of searching for mutually beneficial agreements, bargaining over outcomes, and monitoring and enforcing decisions. Two decades ago, Clingermayer and Feiock [51] argued that institutions shape participation in public decisions by expanding or contracting the scope of issues about which citizens may participate. Institutions also create incentives for policymakers to supply policies, thus altering the path of sustainability policy in predictable ways.

Although propositions based on the PMF have been empirically examined in studies of local sustainability policy, a full exposition of the framework and its application to sustainability policy has been absent until now. This paper fills this lacuna. In addition, the empirical literature has often referenced the PMF in an overly abstract manner that is disconnected connected with policy-making practice. This essay has attempted to bring the PMF down to earth by elucidating the central concepts with examples offering a more complete description of the mechanisms through which demand and supply forces shape policy actions. Although most applications of PMF have focused on institutional and policy change, we argue that the framework can be applied to gain insights into program and policy instrument design as well.

By linking individual and collective choices, PMF begins to bridge the divide between institutional choice and individual behavior. The PMF can also have an application to policy practitioners because it offers strategies to design programs and policy actions in ways that advance the actors' specific policy goals that are advantaged by specific institutions [30]. Policy suppliers are thus able to target policy design to specific types of citizen and constituency groups.

The PMF lens reveals how policy externalities shape the aggregation of policy demands and resulting policy choices. The efficiency and equity implication of externalities will depend on the interactions of policy demands and institutions. In situations where direct benefits go primarily to well-organized interests, but diffuse publics are impacted positively or negatively by externalities, political institutions that insulate policymakers from citizen pressures and popular demands may reinforce political inequalities and lead to less efficient and equitable outcomes.

Framing political exchanges through the lens of a market facilitates assessments of policy transactions in terms of economic efficiency. By adding political institutions, it also allows for assessments of distributional equity by identifying how specific institutional arrangements favor some types of demanders over others. Yet this parsimony is a disadvantage of PMF. Even when the impacts of institutions are accounted for, the PMF cannot easily capture cultural and contextual variations across communities that can shape sustainability decisions [40,41].

The general framework for policy choice offered by the PMF can be applied to policy actions generally, not just sustainability policy. Nevertheless, the vast majority of empirical studies have been focused on local sustainability policy such as climate and energy policy [11,52], land use development and smart growth policy [8,9,53], and environmental policy. This accumulated work provides strong support for the usefulness of the PM framework for understanding sustainability policy design [12,30], adoption [8], diffusion [54], and implementation $[26,55]$. In addition to extending inquiry to other policy areas, the PMF approach can be enriched by applying it at multiple levels of government, since city-scale climate and sustainability actions can produce regional scale co-benefits [56].

Future research on sustainability can focus on individual behaviors of policy actors responsible for designing adopting and implementing sustainability programs. By linking 
individual and collective choices, PMF also takes a step toward bridging the academic divide between institutional/organizational analysis of policymakers' collective decisions and behavioral analysis of the policy responses of policymakers and constituent groups which together shape sustainability policy outcomes. PMF even adds value for assessing applied decision strategies for attaining sustainability policy goals under different institutional arrangements. PMF research can open a broad field for investigations favoring a better understanding of how policy and governance arrangements work, focusing on specific institutional settings and constraints. Thus, it offers a useful conceptual framework for sustainability policy studies and for other fields in the social sciences.

Author Contributions: Conceptualization, R.C.F. and S.K.; methodology, S.K.; writing-original draft preparation, R.C.F.; writing-review and editing, S.K.; visualization, S.K.; funding acquisition, R.C.F. Both authors contributed equally. Both authors have read and agreed to the published version of the manuscript.

Funding: This research was supported by the US National Science Foundation SRN: Integrated Urban Infrastructure Solutions for Environmentally Sustainable, Healthy and Livable Cities, Award Number: 1444745.

Institutional Review Board Statement: Not applicable.

Informed Consent Statement: Not applicable.

Data Availability Statement: Not applicable.

Conflicts of Interest: The authors declare no conflict of interest.

\section{References}

1. Gerber, E. The Populist Paradox; Princeton University Press: Princeton, NJ, USA, 2011.

2. Anderson, S.E.; DeLeo, R.A.; Taylor, K. Policy entrepreneurs, legislators, and agenda setting: Information and influence. Policy Stud. J. 2020, 4, 587-611. [CrossRef]

3. Horn, M. The Political Economy of Public Administration: Institutional Choice in the Public Sector; Cambridge University Press: New York, NY, USA, 1995.

4. Scartascini, C. The Institutional Determinants of Political Transactions; Research Department Working paper series; Inter-American Development Bank: Washington, DC, USA, 2007.

5. Dixit, A. The Making of Economic Policy: A Transaction Cost Politics Perspective; MIT Press: Cambridge, MA, USA, 1996.

6. Grindle, M.; Thomas, J. Policy makers, policy choices and policy outcomes: The political economy of reform in developing countries. Policy Sci. 1989, 22, 213-248. [CrossRef]

7. Haelg, L.; Sewerin, S.; Schmidt, T. The role of actors in the policy design process: Introducing design coalitions to explain policy output. Policy Sci. 2020, 53, 309-347. [CrossRef]

8. Lubell, M.; Feiock, R.C.; Ramirez, E. Political institutions and conservation by local governments. Urban Aff. Rev. 2005, 40, 706-729. [CrossRef]

9. Lubell, M.; Feiock, R.C.; Ramirez, E. Local institutions and the politics of urban growth. Am. J. Political Sci. $2009,53,649-665$. [CrossRef]

10. Andrew, S. Regional integration through contracting networks: An empirical analysis of institutional collection action framework. Urban Aff. Rev. 2009, 44, 378-402. [CrossRef]

11. Tong, K.; Zhao, Z.; Feiock, R.C.; Ramaswami, A. Patterns of urban infrastructure capital investment in Chinese cities and explanation through a political market lens. J. Urban Aff. 2019, 41, 248-263. [CrossRef]

12. Tavares, A.F.; da Cruz, N.F. Explaining the transparency of local government websites through a political market framework. Gov. Inf. Q. 2020, 37, 101249-101270. [CrossRef]

13. Macey, J. Transaction costs and the normative elements of the public choice model: An application to constitutional theory. VA Law Rev. 1998, 74, 471-518. [CrossRef]

14. Williamson, O. Transaction cost economics: How it works; where it is headed. Economist 1998, 146, 23-58. [CrossRef]

15. Libecap, G. Contracting for Property Rights; Cambridge University Press: New York, NY, USA, 1989.

16. Alchian, A.; Demsetz, H. Production, information costs, and economic organization. Am. Econ. Rev. 1973, 62, 777-795.

17. Alston, L.J. Empirical work in institutional economics. In Empirical Studies in Institutional Change; Alston, L.J., Eggertsson, T., North, D.C., Eds.; Cambridge University Press: Cambridge, UK, 1996.

18. North, D.C. Institutions, Institutional Change and Economic Performance; Cambridge University Press: New York, NY, USA, 1990.

19. Baumgartner, F.; Jones, B. Agendas and Instability in American Politics; The University of Chicago Press: Chicago, IL, USA, 1993.

20. Williamson, O. The Economic Institutions of Capitalism; The Free Press: New York, NY, USA, 1985. 
21. Shrestha, M. Network structures and spinoff effects in a collaborative public programs. Public Perform. Manag. Rev. 2019, 42, 976-1003. [CrossRef]

22. Frant, H. High-powered and low-powered incentives in the public sector. J. Public Adm. Res. Theory 1996, 6, 365-381. [CrossRef]

23. Maser, S.M. Constitutions as relational contracts: Explaining procedural safeguards in municipal charters. J. Public Adm. Res. Theory 1998, 8, 527-564. [CrossRef]

24. Feiock, R.C. A Quasi-market framework for local economic development competition. J. Urban Aff. 2002, 24, 123-142. [CrossRef]

25. Deslatte, A. Managerial friction and land-use policy punctuations in the fragmented metropolis. Policy Stud. J. 2018, 48, 700-726. [CrossRef]

26. Lee, Y. Impact Fees Decision Mechanism: Growth Management Decisions in Local Political Market. Int. Rev. Public Adm. 2010, 15, 59-72. [CrossRef]

27. Riker, W. Liberalism Against Populism: A Confrontation Between the Theory of Democracy and the Theory of Social Choice; W.H. Freeman: San Francisco, CA, USA, 1982.

28. Feiock, R. Rational Choice and Regional Governance. J. Urban Aff. 2007, 29, 49-65. [CrossRef]

29. Schneider, M.; Teske, P. Toward a theory of the political entrepreneur: Evidence from local government. Am. Political Sci. Rev. 1992, 86, 737-747. [CrossRef]

30. Curley, C.; Feiock, R.C.; Xu, K. Policy analysis of instrument design: How policy design affects policy constituency. J. Comp. Policy Anal. Res. Pract. 2020, 22, 536-557. [CrossRef]

31. Williamson, O. Public and private bureaucracies: A transaction cost economics perspective. J. Lawecon. Organ. 1999, 15, 306-342. [CrossRef]

32. Stokan, E.; Deslatte, A. Beyond borders: Governmental fragmentation and the political market for growth in American cities. State Local Gov. Rev. 2019, 51, 150-167. [CrossRef]

33. Clingermayer, J. Choice of constituency and representation in urban politics. Mid-Am. J. Politics 1985, 2, 100-109.

34. Carr, J.B. What have we learned about the performance of council-manager government? A review and synthesis of the research. Public Adm. Rev. 2015, 75, 673-689. [CrossRef]

35. Carr, J.B.; Karuppusamy, S. The adapted cities framework: On enhancing its use in empirical research. Urban Aff. Rev. 2008, 43, 875-886. [CrossRef]

36. Deslatte, A.; Feiock, R.C. The Collaboration risk scape: Fragmentation, problem types and preference divergence in urban sustainability. Publius J. Fed. 2019, 49, 352-377. [CrossRef]

37. Deslatte, A. Citizen assessments of local government sustainability performance: A Bayesian approach. J. Behav. Public Adm. 2019, 2, 1-12.

38. Godwin, R.K.; Shepard, W.B. Political processes and public expenditures: A re-examination based on theories of representative government. Am. Political Sci. Rev. 1976, 70, 1127-1135. [CrossRef]

39. Lubell, M. Collaborative institutions, belief systems, and perceived policy effectiveness. Political Res. Q. 2003, 56, 309-323. [CrossRef]

40. Saha, D. Empirical research on local government sustainability efforts in the USA: Gaps in the current literature. Local Environ. 2009, 14, 17-30. [CrossRef]

41. Laurian, L.; Walker, M.; Crawford, J. Implementing environmental sustainability in local government: The impacts of framing, agency culture, and structure in US cities and counties. Int. J. Public Adm. 2017, 40, 270-283. [CrossRef]

42. Hayes, A.F. Introduction to Mediation, Moderation, and Conditional Process Analysis; Guilford Press: New York, NY, USA, 2017.

43. Baron, R.M.; Kenny, D.A. The moderator-mediator variable distinction in social psychological research: Conceptual, strategic, and statistical considerations. J. Pers. Soc. Psychol. 1986, 51, 1173-1182. [CrossRef] [PubMed]

44. Hayes, A.F. Beyond Baron and Kenny: Statistical mediation analysis in the new millennium. Commun. Monogr. 2009, 76, 408-420. [CrossRef]

45. MacKinnon, D.P. Integrating mediators and moderators in research design. Res. Soc. Work Pr. 2011, 21, 675-681. [CrossRef]

46. Feiock, R.C.; Tavares, A.F.; Lubell, M. Policy instrument choices for growth management and land use regulation. Policy Stud. J. 2008, 36, 461-480. [CrossRef]

47. De la Ramírez, C.E.E. Local political institutions and smart growth: An empirical study of the politics of compact development. Urban Aff. Rev. 2009, 45, 218-246. [CrossRef]

48. Gerber, E.R.; Phillips., J.H. Direct democracy and land use policy: Exchanging public goods for development rights. Urban Stud. 2004, 41, 463-479. [CrossRef]

49. Parks, R.B.; Oakerson, R.J. Metropolitan organization and governance: A local public economy approach. Urban Aff. Q. 1989, 25, 18-29. [CrossRef]

50. Schattschneider, E.E. The Semi-Sovereign People: A Realist's View of American Democracy; Holt, Rinehart and Winston: New York, NY, USA, 1960.

51. Clingermayer, J.C.; Feiock, R.C. Institutional Constraints and Local Policy Choices: An Exploration of Local Governance; State University of New York Press: Albany, NY, USA, 2001.

52. Bae, J.; Feiock, R. Forms of government and climate change policies in U.S. cities. Urban Stud. 2013, 50, 776-788. [CrossRef]

53. Hawkins, C. Competing interests and the political market for smart growth policy. Urban Stud. 2014, 51, 2503-2522. [CrossRef] 
54. Cheng, Q.; Yi, H. Complementarity and substitutability: A review of state level renewable energy policy instrument interactions. Renew. Sustain. Energy Rev. 2010, 67, 683-691. [CrossRef]

55. Feiock, R. Politics, institutions and local land-use regulation. Urban Stud. 2004, 41, 363-377. [CrossRef]

56. Feiock, R.C. City scale vs. regional scale co-benefits of climate and sustainability policy: An institutional collective action analysis. Int. J. Environ. Sci. Nat. Resour. 2021, 26. [CrossRef] 